九州大学学術情報リポジトリ

Kyushu University Institutional Repository

\title{
Production of Goat Milk Antibodies against Cell Surface Protein Antigen-Glucosyltransferase Fusion Protein of Streptococcus mutans
}

Kawagoe, Hiroko

Department of Plant Resources, Graduate School of Bioresource and Bioenvironmental Science, Kyushu University

Oho, Takahiko

Department of Preventive Dentistry, Faculty of Dentistry, Kyushu University

Okano, Kaoru

University Farm, Faculty of Agriculture, Kyushu University

Nakano, Yutaka

University Farm, Faculty of Agriculture, Kyushu University

他

https://doi.org/10.5109/24400

出版情報: 九州大学大学院農学研究院紀要. 45 (2)，pp.495-507，2001-02-28. Kyushu University バージョン：

権利関係 : 


\title{
Production of Goat Milk Antibodies against Cell Surface Protein Antigen-Glucosyltransferase Fusion Protein of Streptococcus mutans
}

\author{
Hiroko Kawagoe*, Takahiko Oho ${ }^{\dagger}$, Kaoru Okano ${ }^{\ddagger}$, Yutaka Nakano $^{\ddagger}$, \\ Yoshitaka Ono**, Yoshihiro Shimazaki ${ }^{\dagger}$, Yoshihisa Yamashita, \\ Toshihiko Koga ${ }^{\dagger}$, Masataka Fukuyama ${ }^{\ddagger}$, and Noboru Fujihara ${ }^{\ddagger}$
}

\footnotetext{
* Department of Plant Resources, Graduate School of Bioresource and Bioenvironmental Science, Kyushu University, Fukuoka 812-8581, ${ }^{\dagger}$ Department of Preventive Dentistry, Faculty of Dentistry, Kyushu University, Fukuoka 812-8582, ” University Farm, Faculty of Agriculture, Kyushu University, Fukuoka 811-2307, and ** Saga University Farm 1841 Kuboizumi, Saga 849-0903. Japan

(Received October 31, 2000 and accepted November 10, 2000)
}

\begin{abstract}
Passive immunization is an effective way to prevent infectious diseases in animals and humans. Several attempts have been made to obtain antibody that is effective against Streptococcus mutans using animals. In this study, we immunized pregnant goats with a protein derived from $S$. mutans. This organism produces two major colonization factors: cell surface protein antigen (PAc) and glucosyltransferases (GTFs). Inhibition of these two factors is predicted to provide protection against dental caries. We used a fusion protein, PAcA-GB, which fuses the saliva-binding alanine-rich region (PAcA) of PAc with the glucan binding (GB) domain of GTF-I, as an immunogen. Normal milk samples from goats that were immunized subcutaneously and re-immunized into lymph nodes contained high titers of antibody specific for the fusion protein. When compared with antibodies purified from nonimmunized milk, the goat IgG antibodies purified from immunized milk inhibited the adhesion of $S$. mutans to saliva-coated hydroxyapatite beads. Total glucan synthesis by GTF-I from $S$. mutans was strongly inhibited by goat IgG antibodies purified from the immunized milk.
\end{abstract}

Key Words: Goat, Milk, Streptococcus mutans, Dental Caries, Passive Immunization

\section{INTRODUCTION}

Numerous attempts have been made to develop immunological methods to control infectious diseases in humans and animals. (Yokoyama et al. 1992, Peralta et al. 1994, Ebina et al. 1996, Rosa et al. 1997). Active immunization is an effective way to induce antibodies in the host, but sometimes the antibodies cross-react with host tissues (Moisset et al. 1994). On the other hand, passive immunization is a practical method using tailor-made antibodies preformed outside the host. Antibodies raised in animals such as goats, cows and hens have been used in passive immunization experiments (Michalek et al. 1987, Miettinen et al. 1990, Hamada et al. 1991).

Dental caries is one of the most common diseases in humans, and Streptococcus mutans has been implicated as the primary causative organism of this disease. $S$.

Supported in part by Grants-in-Aids of Developmental Scientific Research (C) 11672051 (T. O.) from the Ministry of Education, Science, Sport and Culture of Japan and by the Kyushu University Interdisciplinary Programs in Education and Projects in Research Development (T. K.) 
mutans possesses a 190-kDa surface protein antigen (PAc) and glucosyltransferases (GTFs), which are considered to play important roles in colonizing tooth surfaces. The simultaneous inhibition of these colonization factors might protect teeth from dental caries. In a previous study, Yu et al. (1997) constructed a fusion protein PAcA-GB that fuses the saliva-binding alanine-rich region (PAcA) of PAc with the glucan binding (GB) domain of GTF-I. Holstein cows immunized with the fusion protein produced antibodies effective against the protein (Oho et al. 1999). Further experiments are necessary to examine the most effective immunization route for antibody production. Goat milk which resembles cow milk, is a rich source of immunoglobulin. Goat are readily used as experimental animals, since they are smaller than cows and their gestation is shorter.

In this study, we compared the ability of several immunization route to induce high titers of antibodies. We obtained milk containing high titers of immunoglobulins against PAcA-GB by subcutaneous immunization followed by injection into the lymph nodes. In addition, we examined the inhibitory effects of immunoglobulin G (IgG) antibodies purified from immunized milk on the in vitro adhesion of $S$. mutans to saliva-coated hydroxyapatite (S-HA) and the effects on glucan synthesis by GTFs from the organism.

\section{MATERIALS AND METHODS}

Animals and Treatments. Three pregnant Tokara goats were used as test animals. The goats were approximately $2 \mathrm{yr}$ old, and their mean BW was $20 \mathrm{~kg}$. To determine the most effective way to induce antibodies in goat milk, three immunization routes were compared (Figure 1). Goat \#1 was immunized and re-immunized with subcutaneous

$\begin{array}{rllllll} & \text { Day } & & & & \\ & -63 & -42 & -21 & 0 & 14 & 35 \\ \text { Injection time } & 1 \mathrm{st} & 2 \mathrm{nd} & 3 \mathrm{rd} & \text { (delivery) } & 4 \mathrm{th} & 5 \mathrm{th} \\ \text { Immunogen } & 5.0 \mathrm{mg} & 2.5 \mathrm{mg} & 2.5 \mathrm{mg} & & 2.5 \mathrm{mg} & 2.5 \mathrm{mg} \\ \text { Adjuvant } & \text { FCA } & \text { FIA } & \text { FIA } & & \text { FIA } & \text { FIA }\end{array}$

Immunization route

$\begin{array}{llllll}\text { Goat \#1 } & \text { SC } & \text { SC } & \text { SC } & \text { SC } & \text { SC } \\ \text { Goat \#2 } & \text { SC } & \text { SC } & \text { SC } & \text { LN } & \text { LN } \\ \text { Goat \#3 } & \text { LN } & \text { LN } & \text { LN } & \text { LN } & \text { LN }\end{array}$

Fig. 1. Immunization schedule. Goat \#1 received 3 subcutaneous (SC) injection of 2.5 or $5.0 \mathrm{mg}$ of fusion protein PAcA-GB before delivery and was re-immunized with the same immunogen subcutaneously after delivery. Goat \#2 was immunized subcutaneously 3 times before delivery and re-immunized by injection into the lymph nodes (LN). Goat \#3 was immunized into the lymph nodes 3 times before delivery and re-immunized by injection into the lymph nodes. The immunogen was emulsified in either Freund's complete adjuvant (FCA) or Freund's incomplete adjuvant (FIA). 
injections. Goat \#2 was immunized with subcutaneous injections and re-immunized into the lymph nodes. Goat \#3 was immunized and re-immunized into the lymph nodes. Approximately 9 weeks prior to the calculated date of delivery, the goats were immunized three times with either 2.5 or $5 \mathrm{mg}$ of protein emulsified in Freund's complete adjuvant or Freund's incomplete adjuvant (Difco Laboratories, Detroit, MI). In order to induce high levels of antibodies in normal milk, the goats were re-immunized with $2.5 \mathrm{mg}$ of the protein emulsified in Freund's incomplete adjuvant in the manners shown in Figure 1. Control goats \#4 and \#5 did not receive any injections of immunogen.

Bacterial strains. The bacterial strains used in this study are listed in Table 1 . The media used were $2 \times$ TY broth (Laloi et al. 1996) for Escherichia coli and brain heart infusion (BHI; Difco Laboratories) broth for S. mutans.

Purification of the fusion protein PAcA-GB. The fusion protein PAcA-GB was purified according to the method described previously (Yu et al. 1997). Briefly, E. coli XL1-Blue harboring the plasmid expressing the PAcA-GB was incubated in $2 \times$ TY broth. The cells were harvested by centrifugation and one-step purification of the fusion proteins with a Qiagen kit was performed using a Ni-nitriloacetic acid resin column according to the manufacturer's directions (Qiagen Inc., Chatworth, CA). The purified fusion protein was analyzed by sodium dodecyl sulfate-polyacrylamide gel electrophoresis (SDS-PAGE) followed by immunoblotting.

Preparation of rPAc. Recombinant PAc (rPAc) was purified from the supernatants of $S$. mutans TK18 cultures by ammonium sulfate precipitation and chromatography on DEAE-cellulose and subsequent gel filtration on Sepharose CL-6B (Pharmacia, Uppsala, Sweden) (Koga et al. 1990).

Preparation of GTFs. Cell-free and cell-associated GTFs were prepared as described by Hamada et al. (1989). In brief, $S$. mutans strains were grown in BHI broth for $18 \mathrm{~h}$ at $37^{\circ} \mathrm{C}$. Cell-associated GTF was extracted from whole cells of $S$. mutans

Table 1. The bacterial strains used in this study

\begin{tabular}{|c|c|c|}
\hline Strain & Description & Reference \\
\hline \multicolumn{3}{|l|}{ S. mutans } \\
\hline MT8148 & Serotype c, $p a c^{+} g t f B^{+} g t f C^{+} g t f D^{+} f t f^{+}$ & Koga et al. (1990) \\
\hline TK18 & $\begin{array}{l}\text { Serotype c, Em } \mathrm{Em}^{\mathrm{r}} \mathrm{gtfB^{+ }} g t f \mathrm{C}^{+} g t f \mathrm{D}^{+} \\
f t f^{+} \text {transformant of GS-5 with pSM1 }\end{array}$ & Koga et al. (1990) \\
\hline $\mathrm{UA}^{130 \mathrm{~B}^{+}}$ & $\begin{array}{l}\text { Serotype c; } \mathrm{Em}^{\mathrm{r}} \mathrm{Te}^{\mathrm{r}} \mathrm{Sm}^{r} ; \text { transformant of } \\
\mathrm{UA130C} ; \text { pac }^{+} \text {gtfB }{ }^{+} \text {gtfC gtfD } \mathrm{ftf}\end{array}$ & Yu et al. (1997) \\
\hline $\mathrm{UA}^{130 \mathrm{C}^{+}}$ & $\begin{array}{l}\text { Serotype c; } \mathrm{Em}^{\mathrm{r}} \mathrm{Te}^{\mathrm{r}} \mathrm{Sm} \text {; transformant of } \\
\text { UA130B; } p a c^{+} g t f C^{+} g t f B \text { gtfD } f t f\end{array}$ & Yu et al. (1997) \\
\hline $\mathrm{UA} 130 \mathrm{D}^{+}$ & $\begin{array}{l}\text { Serotype c; } \mathrm{Em}^{r} \mathrm{Te}^{\mathrm{r}} \mathrm{Sm}^{r} ; \text { transformant of } \\
\text { UA130BC; } p a c^{+} \text {gtff }{ }^{+} \text {gtfB gtfC ftf }\end{array}$ & Yuet al. (1997) \\
\hline \multicolumn{3}{|c|}{ 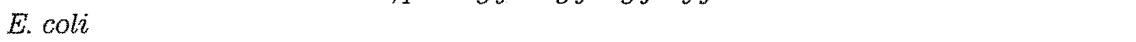 } \\
\hline XL1-Blue & 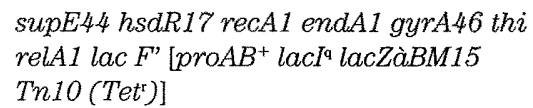 & Yu et al. (1997) \\
\hline
\end{tabular}


MT8148 by treatment with $8 M$ urea at $25^{\circ} \mathrm{C}$ for $1 \mathrm{~h}$. The extract was separated by centrifugation and dialyzed against $100 \mathrm{mM}$ potassium phosphate buffer (KPB; pH6.0), and the supernatant was used as the cell-associated GTF preparation. Cell-free GTF was prepared from the supernatants of $S$. mutans MT8148 cultures. To examine the effects of antibodies on each GTF of $S$. mutans, transformants producing a single species of GTF were used (Yu et al. 1997). GTF-I and GTF-SI were extracted from whole cells of the transformants $\mathrm{UA} 130 \mathrm{~B}^{+}$and $\mathrm{UAl}_{130 \mathrm{C}^{+}}$by treatment with $8 M$ urea at $25^{\circ} \mathrm{C}$ for $1 \mathrm{~h}$. GTF-S

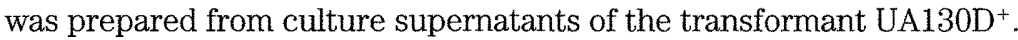

Purification of goat IgG antibody. Colostrum and normal milk, from which the cream had been removed by centrifugation at $4^{\circ} \mathrm{C}(12,000 \times g$ for $15 \mathrm{~min})$, were pasteurized at $65^{\circ} \mathrm{C}$ for $30 \mathrm{~min}$. The milk was adjusted to $\mathrm{pH} 4.6$ with $37 \% \mathrm{HCl}$, and the casein was separated from the whey by centrifugation at $4^{\circ} \mathrm{C}(12,000 \times g$ for $15 \mathrm{~min})$. The $\mathrm{pH}$ of the whey was adjusted to 7.0 with $1 \mathrm{M} \mathrm{NaOH}$. Milk immunoglobulins were concentrated by precipitation with $50 \%$ saturated ammonium sulfate and dialyzed against phosphate-buffered saline (PBS; pH 7.0). For affinity chromatography, the dialyzed immunoglobulin concentrate was applied to HiTrap Protein G column ( $5 \mathrm{~mL}$ ) (Pharmacia) equilibrated with PBS. The column was washed extensively with PBS, and IgG antibody was eluted with $0.1 \mathrm{M}$ glycine- $\mathrm{HCl}$ buffer ( $\mathrm{pH}$ 2.7). The fractions containing IgG antibody were identified by immunoblotting with alkaline phosphatase-conjugated rabbit anti-goat IgG antibody (heavy and light chains) (Zymed Laboratories, South San Francisco, CA.), collected, and used as IgG antibody.

ELISA. For the enzyme--linked immunosorbent assay (ELISA), 96-well microtiter plates were coated with $100 \mu \mathrm{L}$ of $\mathrm{rPAc}$ or GTF-I $(5 \mu \mathrm{g} / \mathrm{mL})$ in $50 \mathrm{mM}$ carbonate-bicarbonate buffer ( $\mathrm{pH} 9.6)$. After overnight incubation at $4^{\circ} \mathrm{C}$, the plates were washed with PBS containing $0.05 \%$ (vol/vol) Tween 20 (PBST) and blocked with PBST containing $1 \%$ (wt/vol) bovine serum albumin. After the plates were washed three times with PBST, twofold serial dilutions of goat milk were added $(100 \mu \mathrm{L}$ per well) and the plates were incubated for $1.5 \mathrm{~h}$ at $37^{\circ} \mathrm{C}$. The bound antibodies were detected with alkaline phosphatase-conjugated rabbit anti-goat IgG antibody (heavy and light chains) (Zymed Laboratories) followed by the addition of $p$-nitrophenylphosphate substrate solution $\left(1 \mathrm{mg} / \mathrm{mL}\right.$ ). After a $30-$ min incubation at $37^{\circ} \mathrm{C}$, the absorbance at $405 \mathrm{~nm}$ (A405) was measured with a microplate reader (Bio-Rad Laboratories, Richmond, CA). The ELISA antibody titer was expressed as the reciprocal of the highest dilution giving an A405 of 0.1 above the conjugated control (no sample added) after a 30 -min incubation with the substrate.

SDS-PAGE and immunoblotting. SDS-PAGE was performed in $7.5 \%$ polyacrylamide gels by the method of Laemmli (1970). rPAc and GTFs were subjected to SDS-PAGE and electrophoretically transferred to a nitrocellulose membrane according to the method of Burnette (1981). After blocking with $1 \%$ bovine serum albumin in Tris-buffered saline ( $20 \mathrm{mM}$ Tris- $\mathrm{HCl}, 150 \mathrm{mM} \mathrm{NaCl}, \mathrm{pH} 7.5$ ) plus $1 \%$ Triton $\mathrm{X}-100$ (TBS-Triton), the membrane was treated with purified goat IgG antibodies. After washing with TBS-Triton, the antibodies bound to proteins immobilized on the membrane were detected with alkaline phosphatase--conjugated rabbit anti-goat IgG antibody (Zymed Laboratories).

Adhesion of $S$. mutans cells to $S-H A$. Unstimulated whole saliva was collected from 
a healthy donor in an ice-chilled tube and clarified by centrifugation. The same source was used for all experiments. Spheroidal hydroxyapatite beads ( $5 \mathrm{mg}$ ) (BDH, Poole, England) were incubated with $200 \mu \mathrm{L}$ of clarified saliva for $1 \mathrm{~h}$ at $37^{\circ} \mathrm{C}$, and washed three times with buffered KCl (Koga et al. 1990). S. mutans MT8148 was grown at $37^{\circ} \mathrm{C}$ for $18 \mathrm{~h}$ in BHI broth, and BCECF-AM [2',7'-bis(2-carboxyethyl)-5(6)-carboxyfluorescein acetoxymethyl ester] was added to the bacterial culture to a final concentration of $10 \mu \mathrm{M}$ and incubated for additional $30 \mathrm{~min}$. BCECF-labeled bacteria $\left(4 \times 10^{7}\right)$ were allowed to react with S-HA beads ( $5 \mathrm{mg}$ ) in $200 \mu \mathrm{L}$ of buffered $\mathrm{KCl}$. After incubation at $37^{\circ} \mathrm{C}$ for $3 \mathrm{~h}$, the beads were washed three times with buffered $\mathrm{KCl}$ and the fluorescence associated with the S-HA beads was determined with a Spectramax Gemini microplate reader (Molecular Devices, Sunnyvale, CA). The number of bacteria adsorbed was determined from the calculated specific fluorescence intensity of the bacteria. To evaluate the inhibitory effects of antibodies on the adherence of $S$. mutans cells to S-HA beads, BCECF-labeled bacteria $\left(4 \times 10^{7}\right)$ were allowed to react with S-HA beads $(5 \mathrm{mg})$ in $200 \mu \mathrm{L}$ of buffered $\mathrm{KCl}$ containing various amounts of IgG antibodies at $37^{\circ} \mathrm{C}$ for $3 \mathrm{~h}$.

GTF assay. The total amount of glucan synthesized by GTF was measured. The standard reaction mixture containing $1 \%$ sucrose (wt/vol) and GTF preparation (2.5 $\mu \mathrm{g}$ of protein) in a total volume of $50 \mu \mathrm{L}$ of $\mathrm{KPB}(\mathrm{pH} 6.0)$ was incubated at $37^{\circ} \mathrm{C}$ for $3 \mathrm{~h}$. After incubation, $75 \mu \mathrm{L}$ of $100 \%$ ethanol were added to the mixture, and synthesized glucan was precipitated at $-30^{\circ} \mathrm{C}$ for $30 \mathrm{~min}$. The precipitated glucan was separated by centrifugation and washed three times with $60 \%$ ethanol. The precipitates were suspended in $50 \mu \mathrm{L}$ of $\mathrm{KPB}$ (pH 6.0) and the total amount of glucan was determined by the phenol-sulfuric acid method using glucose as a standard (Dubois et al., 1956). To examine the inhibitory effects of antibodies on the glucan synthesis catalyzed by GTF, various amounts of IgG antibodies were added to the reaction mixtures.

\section{RESULTS AND DISCUSSION}

Antibody titer in milk. Immunization with the PAcA-GB fusion protein raised the immunoglobulin antibody titers in colostrum and normal milk. The time course for the antibody titers is shown in Figure 2A, B and C. Very high titers against rPAc and GTF-I were detected in colostrum, but these titers decreased rapidly. In order to raise the antibody titers in normal milk, the goats were re-immunized with the fusion protein in different ways on day 14 after delivery. The antibody titers subsequently increased in the milk from goats \#1 and 2. Milk from goat \#2, which was re-immunized into the lymph nodes, contained higher titers of antibody than milk from goat \#1. In goat \#2, the high antibody titers persisted for about 50 days. The antibody titers in the milk of goat \#3 did not increase. On the other hand, the antibody titers were very low in the colostrum and normal milk from nonimmunized goats \#4 and \#5 (data not shown).

Ruminant milk has been used as a means of passive immunization in preventive measures targeting several pathogens (Pasieka et al. 1976, Murosaki et al. 1991, Ishida et al. 1992, Takahashi et al. 1992). The route of immunization of a commercially available E. coli J5 bacterin has been investigated (Tomita et al. 1998). Cows were immunized with $E$. coli $\mathrm{J} 5$ in the neck or in the vicinity of the supramammary lymph nodes, and the antibody titers of cows immunized in either location were similar in magnitude and 

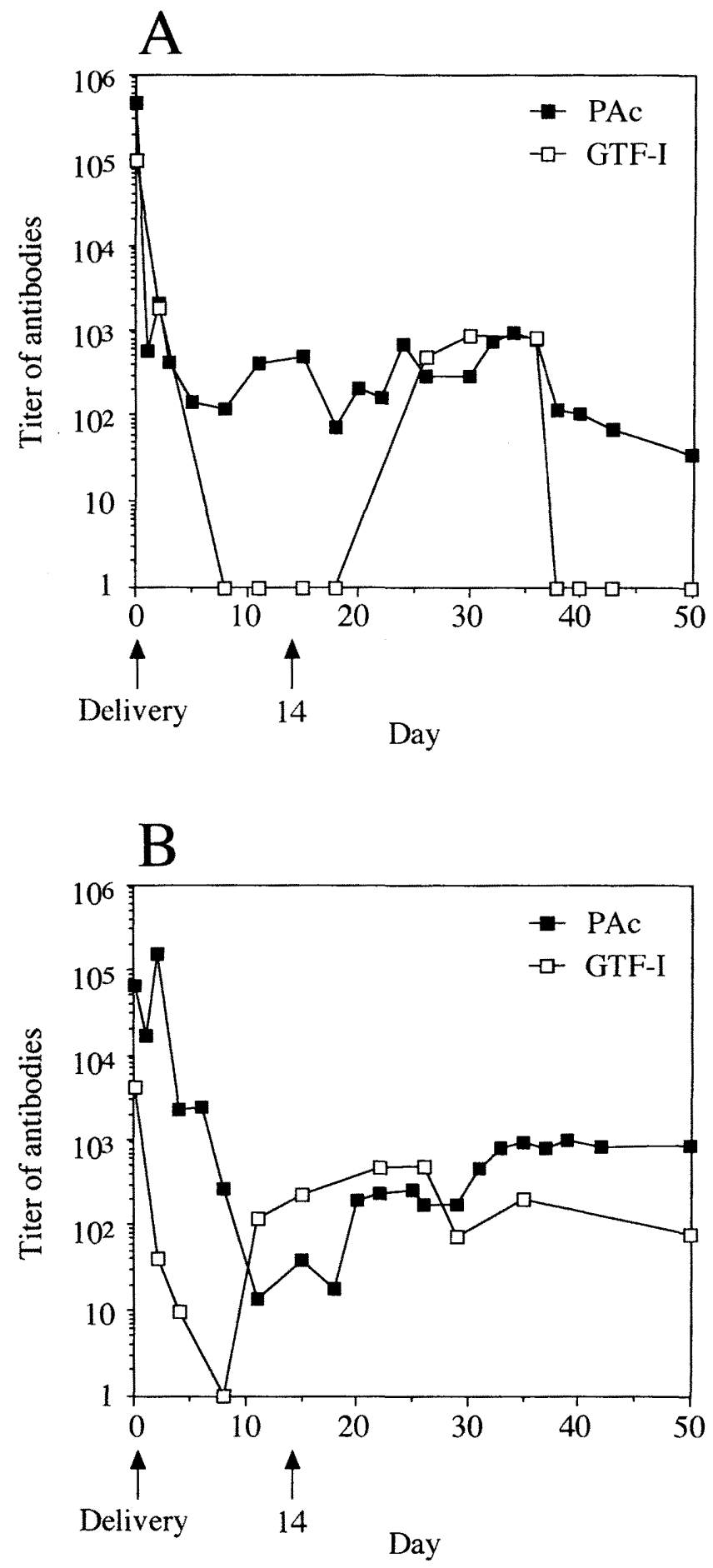


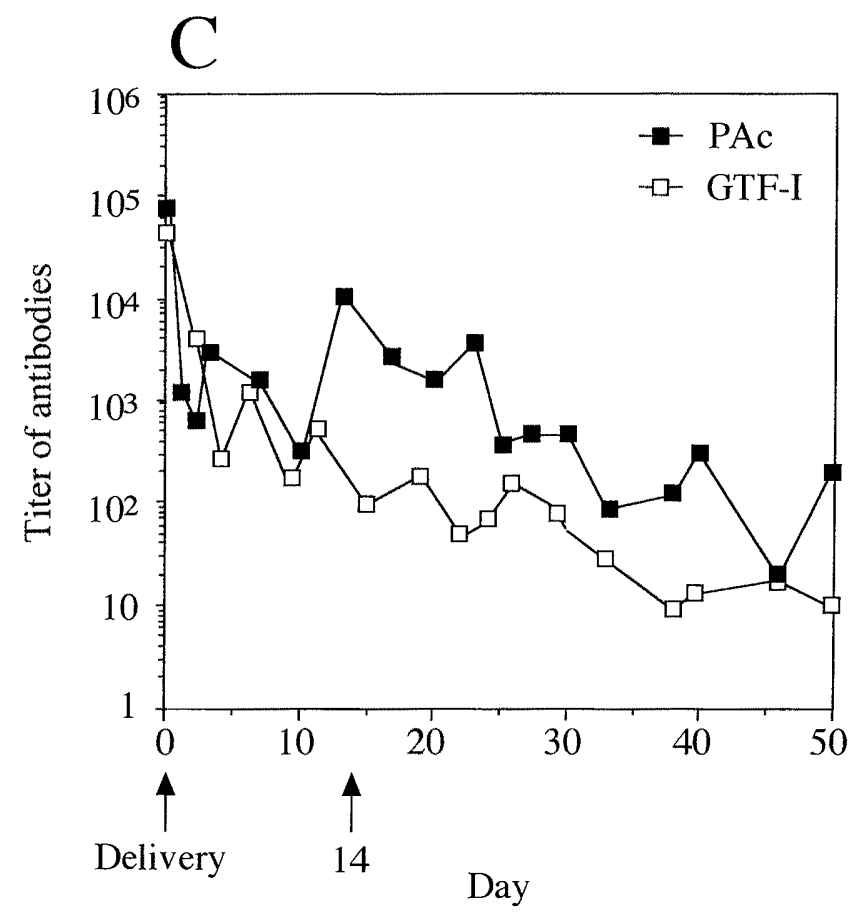

Fig. 2. ELISA titers of goat milk immunoglobulins to rPAC and GTF-I. Goat \#1 was immunized and re-immunized subcutaneouly $(A)$. Goat \#2 was immunized subcutaneously and re-immunized into the lymph nodes $(B)$. Goat \#3 was immunized and re-immunized into the lymph nodes $(C)$. The titers are expressed as the reciprocal of the highest dilution giving an $\mathrm{A} 405$ of 0.1 above the conjugated control (no sample added) after a 30-min of incubation with the substrate. Symbols: - immunoglobulin titers to rPAc; $-\square-$, immunoglobulin titers to GTF-I.

duration. However, Nickerson et al. (1993) demonstrated that immunizing of cows with Staphylococcus aureus bacterin in the area of the supramammary lymph nodes or by intramuscular immunization enhanced the local immune response in the mammary gland. Immunization via supramammary lymph nodes increased the number of cells producing antibody in mammary tissue. Similarly, a pilot study employing $\mathrm{J} \bullet \mathrm{VAC}^{\mathrm{TM}}$ suggested that immunization in the area of the supramammary lymph nodes initiated a greater immune response than subcutaneous or intramuscular immunization (Nickerson, 1995). In this study, subcutaneous immunization followed by re-immunization into lymph nodes was most effective in inducing high titers of antibody in normal milk. A similar mechanism might operate after re-immunization into lymph nodes.

Preparation of goat IgG antibodies. For subsequent inhibition experiments, IgG antibodies from immunized (\#2) and nonimmunized (\#4) milk were purified by affinity chromatography. They were used as IgG antibodies against PAcA-GB and control IgG, 
respectively. The specificities of the IgG antibodies were examined by immunoblotting. The IgG antibodies purified from immunized milk reacted with $\mathrm{PPAc}$ and GTF-I (Figure 3, lanes 2 and 4), while the IgG antibodies purified from nonimmunized milk did not react with antigens (Figure 3, lanes 1 and 3).

In ruminants, including goats, IgG is the predominant immunoglobulin class in colostrum and normal milk (Askonas et al. 1954, Lascelles 1979, Larson et al. 1980), while immunoglobulin M (Hammer et al 1968) and immunoglobulin A (IgA) (Butler 1971, Mach and Pahud 1971) are present in colostrum. IgA is most abundant in most other external secretions, including salivary, lacrimal, nasal, and gastrointestinal secretions. Immunoglobulins, mostly IgG, are either transported from the blood to the colostrum or synthesized locally by the mammary gland (Micusan et al. 1976). IgG antibodies were therefore purified from goat milk and were used for our inhibition experiments.

Inhibition of bacterial adhesion to $S-H A$. The effect of normal milk IgG antibodies on the adhesion of $S$. mutans MT8148 cells to S-HA beads was examined. The IgG antibodies against PAcA-GB strongly inhibited the adhesion of $S$. mutans cells in a

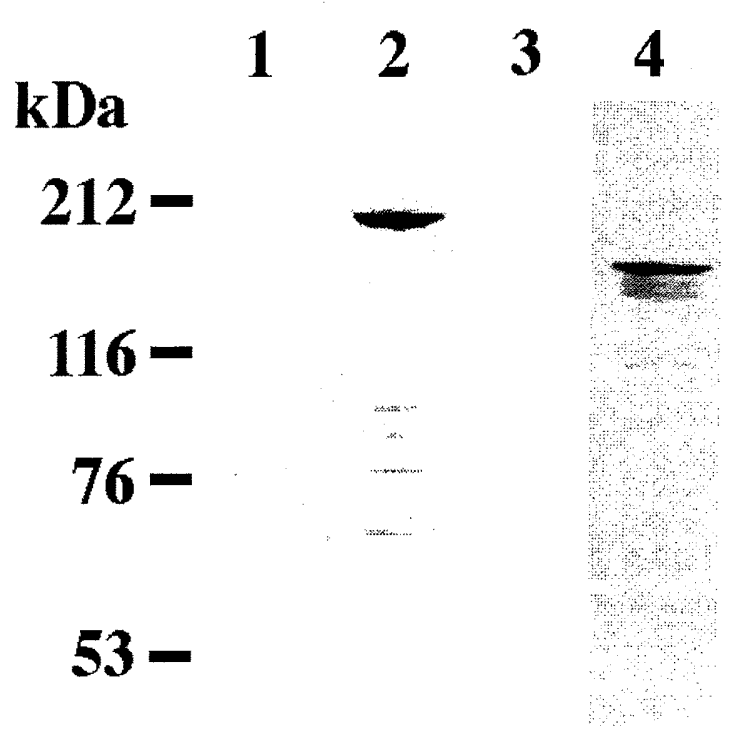

Fig. 3. The specificity of goat milk IgG antibodies against PAcA-GB. Purified antigen samples ( $1 \mu \mathrm{g}$ each) were suspended in SDS-PAGE reducing buffer ( $1 \%$ SDS, $1 \%$ 2-mercaptoethanol) and heated at $100^{\circ} \mathrm{C}$ for $3 \mathrm{~min}$. The samples were subjected to SDS-PAGE (7.5\% polyacrylamide) and then electrophoretically transferred to nitrocellulose membranes. The membranes were reacted with goat IgG antibody purified from the milk of nonimmunized goat \#4 (lanes 1 and 3) and IgG antibody purified from the milk of immunized goat \#2 (lanes 2 and 4). Lanes: 1 and 2, rPAc; 3 and 4, GTF-I. 
dose-dependent manner, but the degree of inhibition by the IgG purified from nonimmunized milk was low (Figure 4). Adsorption of the organism to an acquired pellicle formed on the tooth surface is thought to initiate colonization of the tooth surface by $S$. mutans (Koga et al. 1990). PAc is one of the factors that mediate binding of the organism to the tooth surface. Nakai et al. (1993) used several truncated PAc fragments to show that the A region is the functional domain for PAc binding. IgG antibodies against PAcA-GB inhibited the adhesion of the organism, which suggests that inactivation of the functional domain of PAc might prevent dental caries.

Inhibition of GTFs. Glucan synthesis by cell-associated and cell-free GTF preparations from $S$. mutans MT8148 was investigated. Although the difference was not significant, the addition of IgG antibodies against PAcA-GB inhibited glucan synthsis to a larger extent than the addition of IgG antibodies from nonimmunized milk (Figure 5A and B). Further experiments were performed with three forms of GTF prepared from

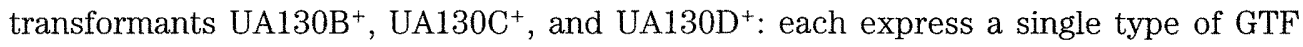
(GTF-I, GTF-SI, and GTF-S, respectively). The IgG antibodies against PAcA-GB markedly inhibited glucan synthesis by GTF-I (Table 2).

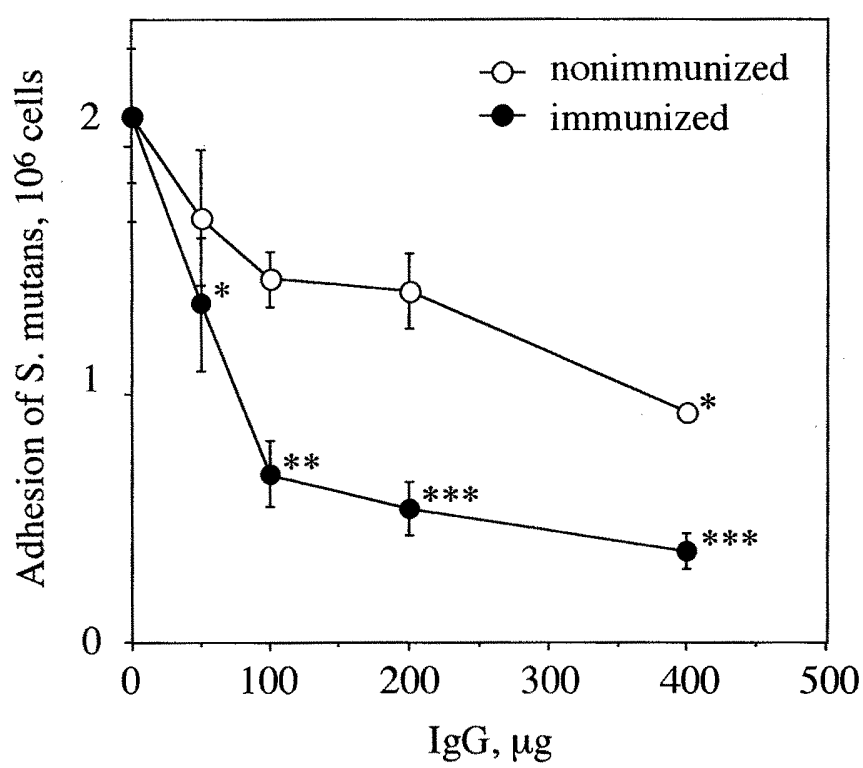

Fig. 4. Inhibition of adhesion of $S$. mutans to S-HA beads by goat IgG antibodies. BCECF-labeled $S$. mutans MT8148 cells $\left(4 \times 10^{7}\right)$ were allowed to react with $5 \mathrm{mg}$ of S-HA beads with various amounts of IgG antibodies purified from the milk of either immunized goat \#2 (-)) or nonimmunized goat \#4 (-O). The values are reported as the means \pm standard deviations of triplicate assays. The experiments were performed three times, and similar results were obtained in each experiment. Single asterisk, $P<0.05$; double asterisk, $P<0.01$; triple asterisk, $P<$ 0.001 compared with control. 

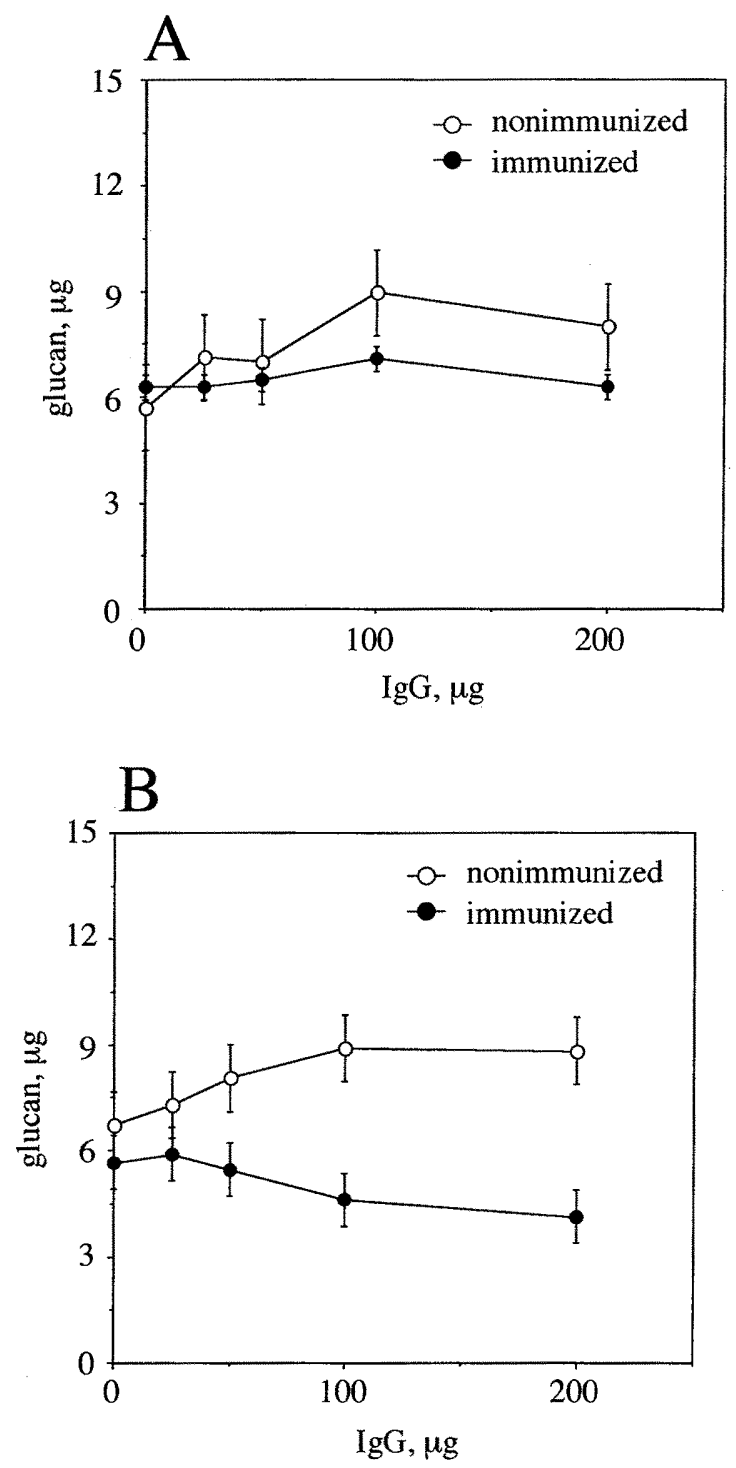

Fig. 5. Effects of goat IgG antibodies on glucan synthesis by crude GTF preparations from $S$. mutans MT8148. (A) Cell-associated GTF, $(B)$ cell-free GTF. The reaction mixture consisted of $1 \%$ (wt/vol) sucrose, crude GTF preparation (2.5 $\mu \mathrm{g}$ of protein), and goat IgG antibodies purified from the milk of either immunized goat \#2 (-) or nonimmunized goat \#4 $(-0)$ in a total volume of $50 \mu \mathrm{L}$ of $0.1 M \mathrm{KPB}(\mathrm{pH} \mathrm{6.0)}$. After incubation for $3 \mathrm{~h}$ at $37^{\circ} \mathrm{C}$, the total glucan synthesized was measured. Values are reported as the means \pm standard deviations of triplicate assays. The experiments were performed three times, and similar results were obtained in each experiment. 
Table 2. Inhibitory effects of goat IgG antibodies on glucan synthesis catalyzed by $S$. mutans GTFS $^{\mathrm{a}}$

\begin{tabular}{|c|c|c|c|}
\hline \multirow[b]{2}{*}{ Antibody } & \multicolumn{3}{|c|}{ Glucan synthesis $(\mu \mathrm{g})^{\mathrm{b}}$} \\
\hline & $\begin{array}{c}\text { Cell-associated GTF } \\
\text { from UA130B } \\
\text { (GTF-I) }\end{array}$ & $\begin{array}{c}\text { Cell-associated GTF } \\
\text { from UA130C } \\
\text { (GTF-SI) }\end{array}$ & $\begin{array}{l}\text { Cell-free GTF } \\
\text { from UA130D } \\
\text { (GTF-S })\end{array}$ \\
\hline Control & $9.6 \pm 0.07$ & $9.5 \pm 0.09$ & $9.2 \pm 0.02$ \\
\hline Immunized ${ }^{c}$ & $3.9 \pm 0.05^{* *}$ & $8.4 \pm 0.02$ & $8.3 \pm 0.10$ \\
\hline Nonimmunized ${ }^{\mathrm{d}}$ & $8.4 \pm 0.04$ & $10.7 \pm 0.12$ & $10.3 \pm 0.05$ \\
\hline
\end{tabular}

a Each GTF preparation (2.5 $\mu \mathrm{g}$ of protein) was allowed to react with $1 \%$ (wt/vol) sucrose in the absence (control) or presence of purified goat milk IgG antibodies (250 $\mu \mathrm{g}$ ) in a total volume of $50 \mu \mathrm{L}$ of $0.1 \mathrm{M} \mathrm{KPB}(\mathrm{pH} 6.0)$ at $37^{\circ} \mathrm{C}$ for $3 \mathrm{~h}$.

- Total glucan synthesized by each GTF was determined by the phenol-sulfuric acid assay. Values are reported as the means \pm standard deviations of triplicate assays. The experiments were performed three times, and similar results were obtained in each experiment. Double asterisk, $P<0.01$ compared with control.

' IgG antibodies were purified from the milk of immunized goat \#2.

${ }^{d}$ IgG antibodies were purified from the milk of nonimmunized goat \#4.

S. mutans produces both water-soluble and water-insoluble glucan from sucrose by the combined action of three forms of GTF (GTF-I, GTF-SI, and GTF-S) (Kuramitsu et al. 1995). The synthesis of water-insoluble glucan allows $S$. mutans to tenaciously adhere to tooth surfaces and accumulate. GTF-I and GTF-SI, which primarily synthesize water-insoluble glucan from sucrose, are mainly associated with the bacterial cell surface (Hamada et al. 1989). On the other hand, GTF-S is released from the cell surface and synthesizes water--soluble glucan. All three $S$. mutans GTFs possess two functional domains: a sucrose-binding (SB) domain in the N-terminal half of the GTF molecules and a repeated glucan-binding (GB) domain in the $\mathrm{C}$ termini of the enzymes (Kuramitsu et al. 1995). The fusion protein PAcA-GB used as an immunogen in this study was constructed with the A fragment of PAC and the GB domain of GTF-I. Purified IgG antibodies against PAcA-GB inhibited glucan synthesis by GTF-I. This suggests that immunized milk might be effective for controlling dental caries.

\section{LITERATURE CITED}

Askonas, B. A., P. N. Campbell, J. H. Humphrey, and T. S. Work. 1954. The sources of antibody globulin in rabbit milk and goat colostrum. Biochem. J. 56: 597-601.

Burnette, W. N. 1981. Western blotting: electrophoretic transfer of proteins from sodium dodecyl sulfate-polyacrylamide gels to unmodified nitrocellulose and radiographic detection with antibody and radioiodinated protein A. Anal. Biochem. 112: 195-203.

Butler, J. E. 1971. Physicochemical and immunochemical studies on bovine IgA and glycoprotein-a. Biochim. Biophys. Acta. 251: 435-449.

Dubois, M., K. A. Gilles, J. K. Hamilton, P. A. Robers, and F. Smith. 1956. Colorimetric method for determination of sugars and related substances. Anal. Chem. 28: 350-356.

Ebina, T. 1996. Prophylaxis of rotavirus gastroenteritis using immunoglobulin. Arch. Virol. 12: $217-223$. Hamada, S., T. Horikoshi, T. Minami, N. Okahashi, and T. Koga. 1989. Purification and characterization 
of cell-associated glucosyltransferase synthesizing water-insoluble glucan from serotype $c$ Streptococcus mutans. J. Gen. Microbiol. 135: 335-344.

Hamada, S., T. Horikoshi, T. Minami, S. Kawabata, J. Hiraoka, T. Fujiwara, and T. Ooshima. 1991. Oral passive immunization against dental caries in rats by use of hen egg yolk antibodies specific for cell-associated glucosyltransferase of Streptococcus mutans. Infect. Immun. 59: 4161-4167.

Hammer, D. K., B. Kickhoen, and G. Henning. 1968. Molecular classes and properties of antibodies in cattle serum and colostrum synthesized during the primary and secondary response to protein antigens. Eur. J. Biochem. 6: 443-454.

Ishida, A., Y. Yoshikai, S. Murosaki, C. Kubo, Y. Hidaka, and K. Nomoto. 1992. Consumption of milk from cows immunized with intestinal bacteria influences age-related changes in immune competence in mice. J. Nutr. 122: 1875-1883.

Koga, T., N. Okahashi, I. Takahashi, T. Kanamoto, H. Asakawa, and M. Iwaki. 1990. Surface hydrophobicity, adherence, and aggregation of cell surface protein antigen mutants of Streptococcus mutans serotype c. Infect. Immun. 58: 289-296.

Kuramitsu, H. K., M. Smorawinska, Y. J. Nakano, A. Shimamura, and M. Lis. 1995. Analysis of glucan synthesis by Streptococcus mutans. Dev. Biol. Stand. 85: 303-307.

Laemmli, U. K. 1970. Cleavage of structural proteins during the assembly of the head of bacteriophage T4. Nature (Lond:) 227: 680-685.

Laloi, P., C. L. Munro, K. R. Jones, and F. L. Macrina. 1996. Immunologic characteristics of a Streptococcus mutans glucosyltransferase B sucrose-binding site peptide-cholera toxin B-subunit chimeric protein. Infect. Immun. 64: 28-36.

Larson, B. L., H. L. Heary, JR., and J. E. Devery. 1980. Immunoglobulin production and transport by the mammary gland. J. Dairy Sci. 63: 665-671.

Lascelles, A. K. 1979. The immune system of the ruminant mammary gland and its role in the control of mastitis. J. Dairy Sci. 62: 154-160.

Mach, J. -P., and Pahud, J. -J. 1971. Secretory IgA, a major immunoglobulin in most bovine external secretions. J. Immunol. 106: 552-563.

Michalek, S. M., R. L. Gregory, C. Harmon, J. Katz, G. J. Richardson, T. Hilton, S. J. Filler, and J. R. Mcghee. 1987. Protection of gnotobiotic rats against dental caries by passive immunization with bovine milk antibodies to Streptococcus mutans. Infect. Immun. 55: 2341-2347.

Micusan, V. V., and A. G. Borduas. 1976. Preferential transport into colostrum of Fc fragment derived from serum IgG1 immunoglobulin in the goat. Res. Vet. Sci. 21: 150-154.

Miettinen, A., J. Husu, and J. Tuomi. 1990. Serum antibody response to Listeria monocytogenes, listerial excretion, and clinical characteristics in experimentally infected goats. J. Clin. Microbiol. 28: 340-343.

Moisset, A., N. Schatz, Y. Lepoivre, S. Amadio, D. Wachasmann, M. Scholler, and J. -P. Klein. 1994. Conservation of salivary glycoprotein-interacting and human immunoglobulin G-cross-reactive domains of antigen I/II in oral streptococci. Infect. Immun. 62: 184-193.

Murosaki, S., Y. Yoshikai, C. Kubo, A. Ishida, G. Matsuzaki, T. Sato, K. Endo, and K. Nomoto. 1991. Influence of intake of skim milk from cows immunized with intestinal bacterial antigens on onset of renal disease in $(\mathrm{NZB} \AA \sim N \mathrm{NZW}) \mathrm{F}_{1}$ mice fed ad libitum or restricted in energy intake. J. Nutr. 121: 1860-1868.

Nakai, M., N. Okahashi, H. Ohta, and T. Koga. 1993. Saliva-binding region of Streptococcus mutans surface protein antigen. Infect. Immun. 61: 4344-4349.

Nickerson, S. C., W. E. Owens, and R. L. Boddie. 1993. Effect of a Staphylococcus aureus bacterin on serum antibody, new infection, and mammary histology in nonlactating dairy cows. J. Dairy Sci. 76: $1290-1297$.

Oho, T., Y. Shimazaki, M. Mitoma, M. Yoshimura, Y. Yamashita, K. Okano, Y. Nakano, H. Kawagoe, M. Fukuyama, N. Fujihara, and T. Koga. 1999. Bovine milk antibodies against cell surface protein antigen PAc-glucosyltransferase fusion protein suppress cell adhesion and alter glucan synthesis of Streptococcus mutans. J. Nutr. 129: 1836-1841.

Pasieka A. E., F. E. Ashton, R. Wallace, F. Ota, A. Ryan, C. Perusse, and B. B. Diena. 1976. Antibody production in milk serum of goats experimentally infected with Neisseria gonorrhoeae. Can. J. Miclobiol. 22: 1113-1119.

Peralta R. C., H. Yokoyama, Y. Ikemori, M. Kuroki, and Y. Kodama. 1994. Passive immunisation against 
experimental salmonellosis in mice by orally administered hen egg-yolk antibodies specific for 14-kDa fimbriae of Salmonella enteritidis. J. Med. Microbiol. 41: 29-35.

Rosa, C. de la, D. E. Hogue, and M. L. Thonney. 1997. Vaccination schedules to raise antibody concentrations against $\varepsilon$-toxin of Clostridium perfringens in ewes and their triplet lambs. J. Anim. Sci. 75: 2328-2334.

Takahashi, N., G. Eisenhuth, I. Lee, N. Laible, S. Binion, and C. Schachtele. 1992. Immunoglobulins in milk from cows immunized with oral strains of Actinomyces, Prevotella, Porphyromonas, and Fusobacterium. J. Dent. Res. 71: 1509-1515.

Tomita. G. M., S. C. Nickerson, W. E. Owens, and B. Wren. 1998. Influence of route of vaccine administration against experimental intramammary infection caused by Escherichia coli. J. Dairy Sci. 81: 2159-2164.

Yokoyama, H., R. C. Peralta, R. Diaz, S. Sendo, Y. Ikemori, and Y. Kodama. $1992 . \quad$ Passive protective effect of chicken egg yolk immunoglobulins against experimental enterotoxigenic Escherichia coli infection in neonatal piglets. Infect. Immun. 60: 998-1007.

Yu, H., Y. Nakano, Y. Yamashita, T. Oho, and T. Koga. 1997. Effects of antibodies against cell surface protein antigen PAc-glucosyltransferase fusion proteins on glucan synthesis and cell adhesion of Streptococcus mutans. Infect. Immun. 65: 2292-2298. 